Original Article

\title{
Chewing insects, pollinators, and predators on Acacia auriculiformis A. Cunn. ex Beth (Fabales: Fabaceae) plants fertilized with dehydrated sewage sludge
}

\author{
Insetos mastigadores, polinizadores e predadores em plantas de Acacia auriculiformis \\ A. Cunn. ex Beth (Fabales: Fabaceae) fertilizada com lodo de esgoto desidratado
}

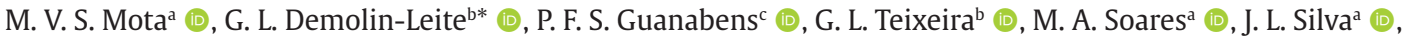 \\ R. A. Sampaio ${ }^{\mathrm{b}}$ (i) and J. C. Zanunciod (i) \\ aUniversidade Federal dos Vales do Jequitinhonha e Mucuri - UFVJM, Departamento de Agronomia, Diamantina, MG, Brasil \\ bUniversidade Federal de Minas Gerais - UFMG, Instituto de Ciências Agrárias, Montes Claros, MG, Brasil \\ Instituto Federal de Minas Gerais - IFMG, Campus de São João Evangelista, São João Evangelista, MG, Brasil \\ dUniversidade Federal de Viçosa - UFV, Instituto de Biotecnologia Aplicada à Agropecuária - BIOAGRO, Departamento de Entomologia, Viçosa, \\ MG, Brasil
}

\begin{abstract}
Fertilization with dehydrated sewage sludge can speed up the recovery process of degraded areas due to nutrients concentration, favoring the development of pioneer plants such as Acacia auriculiformis A. Cunn. ex Beth (Fabales: Fabaceae) and the emergence of insects. This study aimed the evaluation of chewing, pollinating insects, predators, their ecological indices and relationships on A. auriculiformis plants fertilized with dehydrated sewage sludge. The experimental design was completely randomized with two treatments (with and without dehydrated sewage sludge) and 24 repetitions. The prevalence of chewing insects Parasyphraea sp. (Coleoptera: Chrysomelidae), Nasutitermes sp. (Blattodea: Termitidae), and Tropidacris collaris (Stoll, 1813) (Orthoptera: Romaleidae), defoliation, and ecological indices of abundance of Coleoptera and Orthoptera were observed on fertilized A. auriculiformis. Acacia auriculiformis plants, with a superior number of branches/tree, revealed greater abundance of Coleoptera and Orthoptera, species richness of pollinating insects, defoliation, numbers of Parasyphraea sp. and T. collaris. The ones with larger leaves/branches displayed greater abundance of species richness of Coleoptera and Diabrotica speciosa (Germar, 1824) (Coleoptera: Chrysomelidae). Therefore, the use of A. auriculiformis plants, fertilized with dehydrated sewage sludge, is promising in the recovery of degraded areas due to the ecological indices increase of chewing and pollinators insects and spiders in the analyzed area.
\end{abstract}

Keywords: diversity, plant nutrients, degraded area recovery.

\begin{abstract}
Resumo
A fertilização com lodo de esgoto desidratado pode acelerar o processo de recuperação de áreas degradadas devido à concentração de nutrientes, favorecendo o desenvolvimento de plantas pioneiras tais como Acacia auriculiformis A. Cunn. ex Beth (Fabales: Fabaceae) e de seus insetos. O objetivo deste trabalho foi avaliar os insetos mastigadores, polinizadores e predadores e seus índices e relações ecológicas em plantas de A. auriculiformis fertilizadas com lodo de esgoto desidratado, em área degradada, durante 24 meses. $O$ delineamento foi inteiramente casualizados com dois tratamentos (com e sem adubação com lodo de esgoto desidratado) e 24 repetições (uma repetição = uma planta). O maior número de insetos mastigadores Parasyphraea sp. (Coleoptera: Chrysomelidae), Nasutitermes sp. (Blattodea: Termitidae) e Tropidacris collaris (Stoll, 1813) (Orthoptera: Romaleidae), de desfolha, e do índice ecológico abundância de Coleoptera e de Orthoptera foram maiores em plantas de A. auriculiformis fertilizadas do que nas não fertilizadas com lodo de esgoto desidratado. Plantas de A. auriculiformis, com maior quantidade de galhos/árvore, apresentaram maiores abundâncias de Coleoptera e Orthoptera, riqueza de espécies de insetos polinizadores, desfolha e números de Parasyphraea sp. e T. collaris, e as com maior folhas/galho os de riqueza de espécies de Coleoptera e Diabrotica speciosa (Germar, 1824) (Coleoptera: Chrysomelidae). Por tanto, a utilização de A. auriculiformis, adubada com lodo de esgoto desidratado, é promissora na recuperação de áreas degradadas devido ao aumento dos índices ecológicos de insetos mastigadores, polinizadores e aranhas na área.
\end{abstract}

Palavras-chave: diversidade, nutrientes vegetais, recuperação de áreas degradadas.

*e-mail: germano.demolin@gmail.com

Received: February 2, 2021 - Accepted: July 1, 2021 


\section{Introduction}

Brazilian soils are highly weathered, with low chemical quality and fragile macrostructure due to the high temperatures and humidity from the tropical climate (Osei-Tutu et al., 2018). These factors, added to the rapid degradation of organic matter in agricultural areas, promote faster changes in ecosystems than their capacity for natural regeneration (Rojas et al., 2016; Osei-Tutu et al., 2018). The deterioration of ecosystems negatively affects the species richness, abundance, and distribution of plants and animal species, with rare exceptions (generalist species) (Solar et al., 2015). Thus, in significant levels of soil degradation, the application of restoration techniques is favored for the rehabilitation of fauna and flora (Macedo et al., 2008). Thus, one valuable technique available is the application of plants adapted to local conditions (Silva et al., 2020).

Acacia sp. (Fabales: Fabaceae) genus are usually chosen for the recovery of degraded areas because of its rapid growth, biological nitrogen fixation capacity (FBN), and stabilization of organic matter (Hung et al., 2017; Silva et al., 2020). Among the species of the genus, A. auriculiformis A. Cunn. ex Beth stands out for its tolerance to saline environments, along with high $\mathrm{pH}$, and heavy metal levels (Cheung et al., 2000; Rahman et al., 2017). It keeps moisture, hence improves the deposition of potassium and organic carbon in the soil (litter) and can extract heavy metals (with mycorrhizal associations) (Zhu et al., 2016; Muthukumar and Udaiyan, 2018). Acacia auriculiformis is also applied in industry as a wood and cellulose source (Chowdhury et al., 2009).

Sewage sludge can be applied as a fertilizer, mainly in plantations of tree species such as Acacia mangium Willd. (Fabales: Fabaceae) and Pinus radiata D. Don (Pinales: Pinaceae) (Ferreiro-Domínguez et al., 2014; Silva et al., 2020). Its proper application in non-edible cultivation systems that aim minimal environmental impact is relevant due to high-levels of nutrients concentration, pathogens, heavy metals and persistent organic pollutants (Corrêa Martins et al., 2016; Caldeira et al., 2018). Because of its significant content of organic matter and nutrients (Zhou et al., 2019), this fertilizer improves the development of plant species, the physical-chemical and biological properties of the soil and ecological processes (e.g. insect-plant interactions) (Aishah et al., 2016; Wu et al., 2019; Silva et al., 2020). Insects can be applied for monitoring purposes in the recovery processes of degraded areas for their great diversity of species and habitats, and quick response to environmental changes (Pearce and Venier, 2006; Zografou et al., 2017; Silva et al., 2020).

Hypotheses tested interactions among plant, dehydrated sewage sludge, degraded area and ecological indices (diversity and abundance) of arthropods: Plants fertilized with dehydrated sewage sludge will be larger and more complex support a higher insect abundance and diversity owing to bigger and better food availability (i) and, consequently, more arthropod natural enemies (ii) (Silva et al., 2020).

The objective of this study was to evaluate a diversity and abundance of chewing and pollinator insects and arthropod predators on $A$. auriculiformis plants, over 24 months, fertilized with dehydrated sewage sludge in a degraded area.

\section{Material and Methods}

\subsection{Experimental site}

The study was carried out in a degraded area $(\approx 1$ ha $)$ at the "Instituto de Ciências Agrárias da Universidade Federal de Minas Gerais" (ICA/UFMG), Montes Claros, Minas Gerais State, Brazil (latitude 1651'38 S, longitude 445'00" W, altitude $943 \mathrm{~m}$ ) from March 2017 to February 2019. The area was defined as degraded because of soil loss and changes in soil chemistry or hydrology (Whisenant, 1999). The original cerrado vegetation was cut at the end of the 60 s of the last century and pasture was established and, with time, there was a loss of support for cattle and consequent loss of soil.

The climate of the area, according to the Köppen climate classification, is tropical dry, with annual rainfall between 1000 and $1300 \mathrm{~mm}$, dry winter, and average annual temperature $\geq 18^{\circ} \mathrm{C}$ (Alvares et al., 2013). The soil type is litolic neosoil with average texture, total sand = 42.0 dag $\mathrm{Kg}^{-1}$, silt $=36.0 \mathrm{dag} \mathrm{Kg}^{-1}$, clay $=22.0 \mathrm{dag} \mathrm{Kg}^{-1}$, $\mathrm{pH}-\mathrm{H}_{2} \mathrm{O}=5.0$, organic matter $=4.4 \mathrm{dag} \mathrm{Kg}^{-1}, \mathrm{P}=1.5 \mathrm{mg}$ $\mathrm{dm}^{-3}, \mathrm{~K}=92.0 \mathrm{mg} \mathrm{dm}^{-3}, \mathrm{Ca}=1.9 \mathrm{cmolc} \mathrm{dm}^{-3}, \mathrm{Mg}=$ 0.8 cmolc dm $^{-3}, \mathrm{Al}=2.4$ cmolc dm $^{-3}, \mathrm{H}+\mathrm{Al}=6.7 \mathrm{cmolc}$ $\mathrm{dm}^{-3}$, cation-exchange capacity $(\mathrm{CEC})=5.3 \mathrm{cmolc} \mathrm{dm}^{-3}$,

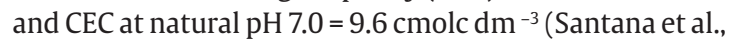
2016) after soil chemical and physical analysis carried out in 2014 in a laboratory using standard international protocols (Pegoraro et al., 2018)

\subsection{Experimental design}

Acacia auriculiformis seeds were accessed from trees grown at ICA/UFMG. Seedlings were produced in a nursery, placed in plastic bags $(8 \times 12 \mathrm{~cm})$, with a mixture of a substrate formed by $30 \%$ organic compost, $30 \%$ clay soil, $30 \%$ sand, and $10 \%$ reactive natural phosphate ( $160 \mathrm{~g} /$ seedling) in March 2016. The organic compost comprises three parts, by volume: two from the remains of milled garden pruning $(\leq 5 \mathrm{~cm})$ and one part of tanned manure. The soil $\mathrm{pH}$, in the holes, was corrected with dolomitic limestone (relative total neutralization power of 90\%) (187 g/hole), increasing the base saturation to 50\% (Kopittke and Menzies, 2007). Natural phosphate $(80 \mathrm{~g})$, fritted trace elements (FTE) (10g), and marble powder $(1 \mathrm{Kg})$ were added per hole, according to the soil analysis. These seedlings were transplanted when $30 \mathrm{~cm}$ tall in holes $(40 \times 40 \times 40 \mathrm{~cm})$, spaced out two meters apart, in six parallel lines on flat ground, spaced out two meters away from each other. 24 plants were fertilized with 20 L of dehydrated sewage sludge/hole, and 24 were not in September 2016.

The seedlings were irrigated twice a week until the beginning of the rainy season, when no additional water was provided. These plants were pruned when their branches reached five $\mathrm{cm}$ using one sterilized razor per plant, with the elimination of additional branches and branches up to $1 / 3$ of the crown height, leaving only the 
best stem out. All pruned parts of the plants were left between their respective planting lines. The design was completely randomized with two treatments (with and without dehydrated sewage sludge) and 24 repetitions (one plant in each repetition). The $20 \mathrm{~L}$ of dehydrated sewage sludge/hole was put in a single dose.

Dehydrated sewage sludge ( $5 \%$ humidity) was collected at the "Estação de Tratamento de Esgoto" (ETE), Juramento, Minas Gerais State, Brazil, about $40 \mathrm{~km}$ from the planting site of A. auriculiformis. ETE is operated by "Companhia de Saneamento de Minas Gerais S.A." (COPASA) and can treat $217 \mathrm{~m}^{3}$ of sewage sludge/day. The efficiency of the system to remove organic matter is over $90 \%$. Sewage sludge went through the solarization process in sand tanks for three months at the ETE, which reduces fecal coliforms to the ideal levels according to the "Conselho Nacional do Meio Ambiente" (CONAMA) (Resolution No. 375) from the "Ministério do Meio Ambiente" of Brazil (http: //www. mma.gov.br/port/conama/res/res06/res37506.pdf) for agriculture which is $<10^{3}$ most likely number/g of total solids. The main chemical and biological characteristics of the dehydrated sewage sludge of this company were $\mathrm{pH}-\mathrm{H}_{2} \mathrm{O}=4.40, \mathrm{~N}=10.4 \mathrm{mg} \mathrm{Kg}^{-1}, \mathrm{P}=2.9 \mathrm{mg} \mathrm{Kg}^{-1}, \mathrm{~K}=$ $5.8 \mathrm{mg} \mathrm{Kg}^{-1}, \mathrm{Cd}=0.1 \mu \mathrm{g} \mathrm{g}^{-1}, \mathrm{~Pb}=56.9 \mu \mathrm{g} \mathrm{g}^{-1}, \mathrm{Cr}=46.7 \mu \mathrm{g}$ $\mathrm{g}^{-1}$ and fecal coliforms $=4.35$ most likely number $\mathrm{g}^{-1}$ after analysis carried out in a laboratory (Nogueira et al., 2007).

\subsection{Arthropods}

Arthropods were counted visually, twice a month, between 7 and $11 \mathrm{AM}$, in the abaxial and adaxial faces of 12 leaves/plant/evaluation, chosen at random, in the apical, middle and basal parts of the canopy, and in the northern, southern, eastern and western orientations. Evaluation was made on each of the $48 \mathrm{~A}$. auriculiformis trees, from six months of age on, for 24 months, totaling a sampling effort of 27,648 leaves. Defoliation caused by insects was evaluated visually by the loss of leaf area on a scale of $0-100 \%$, with increments of $5 \%$ of the leaf area removed in the 48 trees/evaluation (Silva et al., 2020). Insects were not removed from the plants during assessments. Evaluation of the entire plant (vertical and horizontal axes) enabled the sampling of all species of arthropods, especially the rarest ones. The evaluator approached, carefully, firstly assessing the adaxial leaf surface and, if it was not possible to visualize the abaxial one, with a delicate and slow movement, lifting the leaf to visualize it. The position of leaves of $A$. mangium saplings is, in general, tilted upwards, facilitating the visual assessment of arthropods on their leaf surfaces. Insects with greater mobility (e.g. Orthoptera), that flew, on approach, were counted as long as they were recognized (e.g. Order). The arthropods (insects and spiders) were not removed from the saplings during the evaluation.

A few arthropod specimens (up to 3 individuals) per species were collected using an aspirator (two hours per week), at the beginning of the study (between transplantation and first evaluation, six months after), stored in flasks with $70 \%$ alcohol, separated into morphospecies, and sent to specialists for identification (see acknowledgments). Any visible arthropod, not yet computed in previous evaluations, was collected, coded and sent to a taxonomist of its group.

\subsection{Statistical analysis}

Ecological indices (abundance, diversity, and species richness) were calculated for arthropod groups (chewing insects, pollinating insects, and predators) in the treatments (with or without dehydrated sewage sludge)/tree using the program BioDiversity Professional software, Version 2. Abundance and species richness represent the total numbers of individuals and species, respectively, for the sample unit (Begon et al., 2007). Diversity was calculated with the equation Hill formula (1st order): $\mathrm{N} 1=\exp (\mathrm{H}$ '), where $H$ ' is the Shannon-Weaver diversity indices, calculating diversity with the current number of species (Hill, 1973).

The numbers of chewing insects and the percentages of defoliation, pollinating insects and predators and their ecological indices were submitted to the non-parametric statistical hypothesis test, Wilcoxon signed-rank test (P $<0.05$ ) (Wilcoxon, 1946) using the program System for Statistical and Genetic Analysis (SAEG), version 9.1. As the data collected did not present a normal distribution, we chose the non-parametric Wilcoxon test as it is the most powerful test locally among all the classification methods (see Salov, 2014). Data were also subjected to second degree or principal component regressions (PCR), when linear ( $P$ $<0.05$ ) to verify the possible interactions (e.g. predation) between groups of arthropods (e.g. phytophagous insects and spiders).

Simple equations were selected based on the criteria: i) distribution of the data in the figures (linear or quadratic response), ii) the parameters used in these regressions were the most significant ones $(\mathrm{P}<0.05)$, iii) $\mathrm{P}<0.05$ and $F$ of the Analysis of Variance of these regressions, and iv) the determination coefficient of these equations $\left(R^{2}\right)$. PCR model uses principal component analysis, based on a covariance matrix, for the obtention of the regression. This allows the reduction of the dimension of the regression, excluding the dimensions that contribute to collinearity, which are the linear relations between the independent variables (Bair et al., 2006). The parameters, used in these equations, were all significant $(\mathrm{P}<0.05)$ according to the selection of the variables by the "Stepwise" method. The data of leaves/ branch and branches/tree of $A$. auriculiformis, fertilized or not with dehydrated sewage sludge, were described (Dourado et al., 2020).

\section{Results}

The greater number of chewing insects Parasyphraea sp. (Coleoptera: Chrysomelidae), Nasutitermes sp. (Blattodea: Termitidae), and Tropidacris collaris (Stoll, 1813) (Orthoptera: Romaleidae), defoliation and ecological indices of abundance of Coleoptera and Orthoptera were greater in fertilized A. auriculiformis plants than in not fertilized ones. The amount of Aphirape uncifera (Tullgren, 1905) (Araneae: Salticidae) was lower in fertilized plants. Pollinating insects, ecological indices of predators and pollinators did not differ between fertilized and not fertilized plants. 
Acacia auriculiformis plants, with more branches/tree, increased the abundance of Coleoptera and Orthoptera, species richness of pollinating insects, defoliation, numbers of Parasyphraea sp. and T. collaris. Those with largest leaves/branches, increased the species richness of Coleoptera and numbers of Diabrotica speciosa (Germar, 1824) (Coleoptera: Chrysomelidae). Species richness of Orthoptera correlated, positively, with that of spiders, but that of spiders, negatively, with that of Orthoptera. The highest number of arthropods on A. auriculiformis plants comprised phytophagous Stereoma anchoralis (Lacordaire, 1848) (Coleoptera: Chrysomelidae), T. collaris (on the leaves) and Nasutitermes sp. (trunk); pollinator Tetragonisca angustula (latreille, 1811) (Hymenoptera: Apidae); and predator Araneidae (Araneae) (Tables 1-3).

\section{Discussion}

Greater numbers (e.g. Parasyphraea sp.) and ecological indices (e.g. abundance) of chewing insects on leaves with greater defoliation, and on trunks (e.g. Nasutitermes sp.), species richness of pollinating insects, and positive correlation between predators and prey (e.g. Araneae and

Table 1. Number of insects from the Blattodea (Bla.), Coleoptera (Col.), Diptera (Dip.), Lepidoptera (Lep.), Orthoptera (Ort.), and Phasmatidae (Pha.) orders, defoliation (\%), and ecological indices per Acacia auriculiformis trees (mean \pm SE), with and without the application of dehydrated sewage sludge.

\begin{tabular}{|c|c|c|c|c|}
\hline \multirow{2}{*}{ Phytophagous insects } & \multicolumn{2}{|c|}{ Sewage sludge } & \multicolumn{2}{|c|}{$\mathbf{T W}^{*}$} \\
\hline & With & Without & VTE & $\boldsymbol{P}$ \\
\hline Bla.: Termitidae: Nasutitermes sp. ${ }^{\S}$ & $6.67 \pm 3.69$ & $0.00 \pm 0.00$ & 1.8 & 0.04 \\
\hline Col.: Cerambycidae: not identified & $0.04 \pm 0.04$ & $0.00 \pm 0.00$ & 1.0 & 0.16 \\
\hline Chysomelidae: Alagoasa sp. & $0.08 \pm 0.05$ & $0.00 \pm 0.00$ & 1.4 & 0.08 \\
\hline Cerotoma sp. & $0.25 \pm 0.12$ & $0.08 \pm 0.05$ & 0.9 & 0.18 \\
\hline Charidotis sp. & $0.00 \pm 0.00$ & $0.04 \pm 0.04$ & 1.0 & 0.16 \\
\hline Diabrotica speciosa (Germar, 1824) & $0.29 \pm 0.11$ & $0.08 \pm 0.05$ & 1.6 & 0.06 \\
\hline Disonycha brasiliensis (Costa Lima, 1954) & $0.00 \pm 0.00$ & $0.08 \pm 0.05$ & 1.4 & 0.08 \\
\hline Eumolpus sp. & $0.00 \pm 0.00$ & $0.08 \pm 0.05$ & 1.4 & 0.08 \\
\hline Parasyphraea sp. & $0.75 \pm 0.26$ & $0.08 \pm 0.05$ & 2.5 & 0.01 \\
\hline Stereoma anchoralis (Lacordaire, 1848) & $1.25 \pm 0.36$ & $0.79 \pm 0.18$ & 0.2 & 0.41 \\
\hline Walterianella sp. & $0.04 \pm 0.04$ & $0.04 \pm 0.04$ & 0.0 & 0.50 \\
\hline Curculionidae: not identified & $0.04 \pm 0.04$ & $0.04 \pm 0.04$ & 0.0 & 0.50 \\
\hline Cratosomus sp. & $0.08 \pm 0.05$ & $0.00 \pm 0.00$ & 1.4 & 0.08 \\
\hline Lordops sp. & $0.04 \pm 0.04$ & $0.08 \pm 0.05$ & 0.6 & 0.28 \\
\hline Naupactus sp. & $0.04 \pm 0.04$ & $0.08 \pm 0.05$ & 0.6 & 0.28 \\
\hline Tenebrionidae: not identified & $0.04 \pm 0.04$ & $0.00 \pm 0.00$ & 1.0 & 0.16 \\
\hline Dip.: Otitidae: Euxesta sp. & $0.08 \pm 0.05$ & $0.13 \pm 0.06$ & 1.0 & 0.17 \\
\hline Lep.: not identified & $0.17 \pm 0.07$ & $0.13 \pm 0.06$ & 0.4 & 0.34 \\
\hline Ort:: Proscopiidae: Cephalocoema sp. & $0.08 \pm 0.05$ & $0.17 \pm 0.09$ & 0.5 & 0.31 \\
\hline Romaleidae: Tropidacris collaris (Stoll, 1813) & $1.29 \pm 0.22$ & $0.46 \pm 0.13$ & 2.8 & 0.00 \\
\hline Tettigoniidae: not identified & $0.79 \pm 0.19$ & $0.58 \pm 0.11$ & 0.5 & 0.32 \\
\hline Pha.: Phasmatidae: Phibalosoma phyllinum (Gray, 1835) & $0.00 \pm 0.00$ & $0.04 \pm 0.04$ & 1.0 & 0.16 \\
\hline \multicolumn{5}{|l|}{ Defoliation and ecological indices } \\
\hline Defoliation (\%) & $4.54 \pm 0.17$ & $3.56 \pm 0.18$ & 3.4 & 0.00 \\
\hline Abundance of Coleoptera & $2.96 \pm 0.54$ & $1.50 \pm 0.25$ & 1.7 & 0.04 \\
\hline Diversity of Coleoptera & $4.18 \pm 0.84$ & $3.50 \pm 0.50$ & 0.4 & 0.35 \\
\hline Species richness of Coleoptera & $1.67 \pm 0.27$ & $1.25 \pm 0.19$ & 1.1 & 0.15 \\
\hline Abundance of Orthoptera & $2.17 \pm 0.30$ & $1.21 \pm 0.20$ & 2.3 & 0.01 \\
\hline Diversity of Orthoptera & $2.90 \pm 0.40$ & $2.64 \pm 0.33$ & 0.2 & 0.43 \\
\hline Species richness of Orthoptera & $1.34 \pm 0.16$ & $1.04 \pm 0.16$ & 1.2 & 0.12 \\
\hline
\end{tabular}

${ }^{*} \mathrm{TW}=$ test of Wilcoxon. $\mathrm{VT}^{£}=$ value of test. $\mathrm{n}=24$ per treatment. ${ }^{\S}=$ observed on trunck. 
Table 2. Number of spiders, pollinating and predator insects from the Araneae (Ara.), Hemiptera (Hem.), Hymenoptera (Hym.), and Mantodea (Man.) orders, and their ecological indices per Acacia auriculiformis plants (mean \pm SE), with and without the application of dehydrated sewage sludge.

\begin{tabular}{|c|c|c|c|c|}
\hline \multirow{2}{*}{ Predadors and pollinators } & \multicolumn{2}{|c|}{ Sewage sludge } & \multicolumn{2}{|c|}{$\mathrm{TW}^{*}$} \\
\hline & With & Without & VTE & $\boldsymbol{P}$ \\
\hline Ara.: Anyphaenidae: Teudis sp. & $0.08 \pm 0.05$ & $0.17 \pm 0.07$ & 1.3 & 0.09 \\
\hline Araneidae: not identified & $0.54 \pm 0.13$ & $0.38 \pm 0.14$ & 1.2 & 0.11 \\
\hline Oxyopidae: not identified & $0.17 \pm 0.09$ & $0.17 \pm 0.09$ & 0.0 & 0.50 \\
\hline Oxyopes salticus (Hentz, 1845) & $0.04 \pm 0.04$ & $0.04 \pm 0.04$ & 0.0 & 0.50 \\
\hline Salticidae: not identified & $0.38 \pm 0.13$ & $0.13 \pm 0.06$ & 1.5 & 0.07 \\
\hline Uspachus sp. & $0.13 \pm 0.09$ & $0.08 \pm 0.05$ & 0.0 & 0.48 \\
\hline Aphirape uncifera (Tullgren, 1905) & $0.00 \pm 0.00$ & $0.13 \pm 0.06$ & 1.8 & 0.04 \\
\hline Sparassidae: Quemedice sp. & $0.08 \pm 0.05$ & $0.04 \pm 0.04$ & 0.6 & 0.28 \\
\hline Tetragnathidae: Leucauge sp. & $0.00 \pm 0.00$ & $0.04 \pm 0.04$ & 1.0 & 0.16 \\
\hline Thomisidae: Tmarus sp. & $0.13 \pm 0.06$ & $0.04 \pm 0.04$ & 1.0 & 0.15 \\
\hline Hem.: Pentatomidae: Podisus sp. & $0.08 \pm 0.05$ & $0.04 \pm 0.04$ & 0.0 & 0.49 \\
\hline Hym.: Apidae: Apis mellifera (Linnaeus, 1758) & $0.38 \pm 0.17$ & $0.13 \pm 0.06$ & 0.9 & 0.20 \\
\hline Tetragonisca angustula (latreille, 1811) & $1.00 \pm 0.37$ & $0.58 \pm 0.13$ & 0.4 & 0.36 \\
\hline Trigona spinipes (Fabricius, 1793) & $0.08 \pm 0.05$ & $0.00 \pm 0.00$ & 1.4 & 0.08 \\
\hline Vespidae: Polybia sp. & $0.60 \pm 0.19$ & $0.33 \pm 0.09$ & 1.0 & 0.17 \\
\hline Mant.: Mantidae: Mantis religiosa (Linnaeus, 1758) & $0.08 \pm 0.05$ & $0.00 \pm 0.00$ & 1.4 & 0.08 \\
\hline \multicolumn{5}{|l|}{ Ecological indices } \\
\hline Abundance of spiders & $1.54 \pm 0.19$ & $1.21 \pm 0.22$ & 1.3 & 0.09 \\
\hline Diversity of spiders & $2.80 \pm 0.32$ & $2.89 \pm 0.45$ & 0.1 & 0.46 \\
\hline Species richness of spiders & $1.25 \pm 0.13$ & $1.05 \pm 0.17$ & 1.0 & 0.15 \\
\hline Abundance of pollinators & $1.46 \pm 0.45$ & $0.71 \pm 0.15$ & 0.3 & 0.39 \\
\hline Diversity of pollinators & $1.93 \pm 0.36$ & $1.95 \pm 0.37$ & 0.2 & 0.42 \\
\hline Species richness of pollinators & $0.63 \pm 0.14$ & $0.63 \pm 0.13$ & 0.1 & 0.46 \\
\hline
\end{tabular}

${ }^{*} \mathrm{TW}=$ test of Wilcoxon. $\mathrm{VT}^{\mathfrak{f}}=$ value of test. $\mathrm{n}=24$ per treatment.

Orthoptera) on A. auriculiformis plants, fertilized with dehydrated sewage sludge, were observed, probably, due to the best development of these plants. Acacia auriculiformis plants, fertilized with dehydrated sewage sludge, have a higher number of leaves per tree (Dourado et al., 2020), similar to what was presented for $A$. mangium with this same fertilizer (Silva et al., 2020), perhaps for sewage sludge being rich in nitrogen (Nogueira et al., 2007).

Bigger numbers (e.g. T. collaris) and ecological indices (e.g. abundance) of chewing insects on the leaves, termites on trunks, and species richness of pollinating insects, with predators chasing their prey (e.g. species richness of spider versus that of Orthoptera), on A. auriculiformis plants, fertilized with dehydrated sewage sludge, was possibly recognized, due to the greatest number of leaves and branches of these plants (Dourado et al., 2020). The plants offered extra food and shelter for herbivorous insects, as reported for A. mangium (Silva et al., 2020), besides the greater amount of litterfall (Dourado et al., 2020), favoring the Termitidae, as observed in larger Caryocar brasiliense
Camb. (Malpighiales: Caryocaracea) trees (Leite et al., 2011). The facts above confirm the hypothesis that ecological indices of chewing insects (e.g. abundance) and pollinators (e.g. species richness) and their predators are higher in trees with superior leaf mass. Similar evidences were reported for Constrictotermes cyphergaster (Silvestri, 1901) (Blattodea: Termitidae), leaf galling insect Eurytoma sp. (Hymenoptera: Eurytomidae) on C. brasiliense trees (Leite et al., 2011, 2017), chewing and pollinator insects and predators on A. mangium plants (Silva et al., 2020), with smaller risk of extinction of rare insect species (Zvereva et al., 2014; Burns, 2016; Leite et al., 2017).

The positive correlation between predators and phytophagous insects on A. auriculiformis plants, was observed, probably, because of the greater complexity of crowns (habitat), especially the fertilized ones, providing indirect benefits to natural enemies, as they hold a higher abundance of phytophagous and increase the chance of rare species incidence (Riihimäki et al., 2006; Burns, 2016). Thus, more developed trees allow a bigger 
Table 3. Relations between abundances (Ab.) of Coleoptera (Col.), Orthoptera (Orth.), species richness (S.R.) of Col. and pollinators (Pol.), percentage of defoliation (Defol.), number of Diabrotica speciosa (D.S.), Parasyphraea sp. (Par.), and Tropidacris collaris (T.col.) with the number of leaves/branch (N.leaves) and/or branches/plant (N.branches), Ab.Orth. with that of spiders (Ab.Spid.), and S.R. Spid. with Ab.Orth and S.R.Orth. on Acacia auriculiformis plants.

\begin{tabular}{|c|c|c|c|}
\hline \multirow{2}{*}{ Principal component regressions } & \multicolumn{3}{|c|}{ ANOVA } \\
\hline & $\mathbf{R}^{2}$ & $\boldsymbol{F}$ & $\boldsymbol{P}$ \\
\hline Ab.Col. $=-0.32+0.07 \times$ N.branches & 0.18 & 10.08 & 0.00 \\
\hline Ab.Orth. $=0.61+0.03 \times$ N.branches & 0.09 & 4.25 & 0.04 \\
\hline S.R.Col. $=-0.65+0.07 \times$ N.leaves & 0.11 & 5.69 & 0.02 \\
\hline S.R.Spid. $=0.74+0.34 \times$ S.R.Orth. & 0.13 & 6.90 & 0.01 \\
\hline Defol. $=2.59+0.04 \times$ N.branches & 0.28 & 17.52 & 0.00 \\
\hline D.S. $=-0.60+0.03 \times$ N.leaves & 0.11 & 5.38 & 0.03 \\
\hline Par. $=-0.68+0.03 \times$ N.branches & 0.17 & 9.14 & 0.00 \\
\hline T.col $=-0.16+0.03 \times$ N.branches & 0.15 & 8.01 & 0.01 \\
\hline \multicolumn{4}{|l|}{ Second-degree regressions } \\
\hline Ab.Orth. $=0.82+1.26 \times$ Ab.Spid. $-0.30 \times$ Ab.Spid. ${ }^{2}$ & 0.13 & 3.33 & 0.04 \\
\hline S.R.Pol. $=4.3-0.22 \times$ N.branches $+29.78 \times$ N.branches ${ }^{2}$ & 0.18 & 5.26 & 0.01 \\
\hline
\end{tabular}

$\mathrm{n}=48$, degrees of freedom: treatment $=1$, repetitions $=22$, and residue $=23$.

number of predators, in response to the way of life and the abundance of their prey (Gagnon and Brodeur, 2014; Burns, 2016). Also, predators have smaller population sizes than their prey, therefore, they must face a stronger probability of extinction, particularly in plants with less development (Zalewski et al., 2018). Interactions between insects and plants of the genus Acacia show the potential of this plant to increase diversity and cover degraded soils around the world (Fleming et al., 2007; McLeish et al., 2007; Silva et al., 2020), including soil macrofauna as Carabidae and Scarabaeidae (Coleoptera) (Larsen et al., 1996; Kitamura et al., 2008).

The chewing insects $S$. anchoralis, $T$. collaris, and Nasutitermes sp. were the ones with larger numbers on $A$. auriculiformis plants, as also documented, for the three insect species, on $A$. mangium plants (Silva et al., 2020). The species S. anchoralis damages A. mangium, and T. collaris, besides attacking Casuarina glauca Sieber (Fagales: Casuarinaceae) and Leucaena leucocephala (Lam.) de Wit (Fabales: Fabaceae) plants (Poderoso et al., 2013; Damascena et al., 2017). Greater numbers of Nasutitermes sp. on the trunks of A. auriculiformis trees, fertilized with dehydrated sewage sludge were observed probably, due to the richness of organic matter in this fertilizer (Nogueira et al., 2007) and the higher litter fall production by the plant (Dourado et al., 2020), also, apparent damage or death of these plants was noted, as on A. mangium plants (Silva et al., 2020).

Nasutitermes sp. can damage live or dead trees and processed wood, including root systems, although it creates galleries in the trunks without causing the death of plants (Albuquerque et al., 2012). Tetragonisca angustula, the biggest pollinator numbers on $A$. auriculiformis plants, is important in the pollination of angiosperms, standing out among other bees, since it has greater eusociality (Giannini et al., 2012; Grüter et al., 2011). Finally, spiders (e.g. Araneidae), on A. auriculiformis plants, stand out since they prey on chewing insects (e.g. T. collaris). Spiders were also prominent, due to their numbers and predations of defoliating insects on $A$. mangium and C. brasiliense trees, in the Brazilian cerrado (Leite et al., 2012; Silva et al., 2020), and on pastures and forests in Greece, being directly correlated with Orthoptera (Zografou et al., 2017).

\section{Conclusion}

Acacia auriculiformis, fertilized with dehydrated sewage sludge, is promising in the recovery of degraded areas, since the fertilized plants are larger and more complex. These plants accept a greater number of chewing insects, pollinators, and predators, because there are more niches and better food quality improving the ecological indices in the area.

\section{Acknowledgements}

To the taxonomists Dr. Antônio Domingos Brescovit (Instituto Butantan, São Paulo State, Brazil) (Arachnida) and Dr. Ayr de Moura Bello (Oswaldo Cruz Foundation, Rio de Janeiro State, Brazil) (Coleoptera), for their identifications. The voucher numbers are IBSP 36921-36924 (Instituto Butantan, São Paulo State, Brazil) and for insects 1595/02 and 1597/02 (UFPR-CDZOO, Paraná State, Brazil). To the "Conselho Nacional de Desenvolvimento Científico e Tecnológico” (CNPq), "Coordenação de Aperfeiçoamento de Pessoal de Nível Superior" (CAPES), "Fundação de Amparo à Pesquisa do Estado de Minas Gerais” (FAPEMIG), and "Programa de Proteção Florestal" (PROTEF) by "Instituto de Pesquisas Florestais” for financial support. 


\section{References}

AISHAH, R.M., SHAMSHUDDIN, J., FAUZIAH, C.I., ARIFIN, A. and PANHWAR, Q.A., 2016. Phytoremediation of copper and zinc in sewage sludge amended soils using Jatropha curcas and Hibiscus cannabinus. Journal of the Chemical Society of Pakistan, vol. 38, no. 6, pp. 1230-1243.

ALBUQUERQUE, A.C., MATIAS, G.R.R.S., OLIVEIRA, M.A.P., COUTO, A.A.V.O. and VASCONCELLOS, A., 2012. Urban termites of recife, Northeast Brazil (Isoptera). Sociobiology, vol. 59, no. 1, pp. 183-188. http://dx.doi.org/10.13102/sociobiology.v59i1.675.

ALVARES, C.A., STAPE, J.L., SENTELHAS, P.C., DE MORAES GONÇALVES, J.L. and SPAROVEK, G., 2013. Köppen's climate classification map for Brazil. Meteorologische Zeitschrift (Berlin), vol. 22, no. 6, pp. 711-728. http://dx.doi.org/10.1127/0941-2948/2013/0507.

BAIR, E., HASTIE, T., PAUL, D. and TIBSHIRANI, R., 2006. Prediction by supervised principal components. Journal of the American Statistical Association, vol. 101, no. 473, pp. 119-137. http:// dx.doi.org/10.1198/016214505000000628.

BEGON, M., TOWNSEND, C.R. and HARPER, J.L., 2007. Ecologia: de indivíduos a ecossistemas. 4. ed. Porto Alegre: Artmed, 752 p.

BURNS, K.C., 2016. Native-exotic richness relationships: a biogeographic approach using turnover in island plant populations. Ecology, vol. 97, no. 11, pp. 2932-2938. http:// dx.doi.org/10.1002/ecy.1579. PMid:27870029.

CALDEIRA, M.V.W., FAVALESSA, M., DELARMELINA, W.M., GONÇALVES, E. and SANTOS MOURA, R.R., 2018. Sewage sludge assessment on growth of Acacia mangium seedlings by principal components analysis and orthogonal contrasts. Journal of Plant Nutrition, vol. 41, no. 10, pp. 1303-1311. http://dx.doi.org/10.1 080/01904167.2018.1450421.

CHEUNG, K.C., WONG, J.P.K., ZHANG, Z.Q., WONG, J.W.C. and WONG, M.H., 2000. Revegetation of lagoon ash using the legume species Acacia auriculiformis and Leucaena leucocephala. Environmental Pollution, vol. 109, no. 1, pp. 75-82. http://dx.doi.org/10.1016/ S0269-7491(99)00235-3. PMid:15092915.

CHOWDHURY, M.Q., ISHIGURI, F., IIZUKA, K., HIRAIWA, T., MATSUMOTO, K., TAKASHIMA, Y., YOKOTA, S. and YOSHIZAWA, N., 2009 [viewed 2 February 2021]. Wood property variation in Acacia auriculiformis growing in Bangladesh. Wood and Fiber Science [online]. vol. 41, no. 4, pp. 359-365. Available from: https://wfs.swst.org/index.php/wfs/article/viewFile/1230/1230

CORRÊA MARTINS, M.N., DE SOUZA, V.V. and SOUZA, T.D.S., 2016. Genotoxic and mutagenic effects of sewage sludge on higher plants. Ecotoxicology and Environmental Safety, vol. 124, pp. 489-496. http://dx.doi.org/10.1016/j.ecoenv.2015.11.031. PMid:26643763.

DAMASCENA, J.G., LEITE, G.L.D., SILVA, F.W.S., SOARES, M.A., GUANABENS, R.E.M., SAMPAIO, R.A. and ZANUNCIO, J.C., 2017. Spatial Distribution of Phytophagous Insects, Natural Enemies, and Pollinators on Leucaena leucocephala (Fabaceae) Trees in the Cerrado. The Florida Entomologist, vol. 100, no. 3, pp. 558565. http://dx.doi.org/10.1653/024.100.0311.

DOURADO, L.R., DEMOLIN-LEITE, G.L., SOARES, M.A., TEIXEIRA, G.L., SILVA, F.W.S., SAMPAIO, R.A., ZANUNCIO, J.C. and LEGASPI, J.C., 2020. Ecological indices of phytophagous Hemiptera and their natural enemies on Acacia auriculiformis (Fabales: Fabaceae) plants with or without dehydrated sewage sludge application in a degraded area. PLoS One, vol. 15, no. 8, pp. e0237261. http:// dx.doi.org/10.1371/journal.pone.0237261. PMid:32804957.

FERREIRO-DOMÍNGUEZ, N., RIGUEIRO-RODRÍGUEZ, A., BIANCHETTO, E. and MOSQUERA-LOSADA, M.R., 2014. Effect of lime and sewage sludge fertilisation on tree and understory interaction in a silvopastoral system. Agriculture, Ecosystems \& Environment, vol. 188, pp. 72-79. http://dx.doi.org/10.1016/j.agee.2014.02.007.

FLEMING, P.A., HOFMEYR, S.D. and NICOLSON, S.W., 2007. Role of insects in the pollination of Acacia nigrescens (Fabaceae). South African Journal of Botany, vol. 73, no. 1, pp. 49-55. http://dx.doi. org/10.1016/j.sajb.2006.06.010.

GAGNON, A.È. and BRODEUR, J., 2014. Impact of plant architecture and extraguild prey density on intraguild predation in an agroecosystem. Entomologia Experimentalis et Applicata, vol. 152, no. 2, pp. 165-173. http://dx.doi.org/10.1111/eea.12213.

GIANNINI, T.C., ACOSTA, A.L., GARÓFALO, C.A., SARAIVA, A.M., ALVES-DOS-SANTOS, I. and IMPERATRIZ-FONSECA, V.L., 2012. Pollination services at risk: bee habitats will decrease owing to climate change in Brazil. Ecological Modelling, vol. 244, pp. 127-131. http://dx.doi.org/10.1016/j.ecolmodel.2012.06.035.

GRÜTER, C., KÄRCHER, M.H. and RATNIEKS, F.L.W., 2011. The natural history of nest defence in a stingless bee, Tetragonisca angustula (Latreille) (Hymenoptera: Apidae), with two distinct types of entrance guards. Neotropical Entomology, vol. 40, no. 1, pp. 55-61. http://dx.doi.org/10.1590/S1519-566X2011000100008. PMid:21437483.

HILL, M.O., 1973. Diversity and Evenness: A Unifying Notation and Its Consequences. Ecology, vol. 54, no. 2, pp. 427-432. http:// dx.doi.org/10.2307/1934352.

HUNG, T.T., DOYLE, R., EYLES, A. and MOHAMMED, C., 2017. Comparison of soil properties under tropical Acacia hybrid plantation and shifting cultivation land use in northern Vietnam. Southern Forests, vol. 79, no. 1, pp. 9-18. http://dx.doi.org/10.2 989/20702620.2016.1225185.

KITAMURA, A.E., ALVES, M.C., SUZUKI, L.G.A.S. and PAZ GONZALEZ, A., 2008. Recuperação de um solo degradado com a aplicação de adubos verdes e lodo de esgoto. Revista Brasileira de Ciência do Solo, vol. 32, no. 1, pp. 405-416. http://dx.doi.org/10.1590/ S0100-06832008000100038.

KOPITTKE, P.M. and MENZIES, N.W., 2007. A review of the use of the basic cation saturation ratio and the "ideal" soil. Soil Science Society of America Journal, vol. 71, no. 2, pp. 259-265. http:// dx.doi.org/10.2136/sssaj2006.0186.

LARSEN, K.J., PURRINGTON, F.F., BREWER, S.R. and TAYLOR, D.H., 1996. Influence of sewage sludge and fertilizer on the ground beetle (Coleoptera: Carabidae) fauna of an old-field community. Environmental Entomology, vol. 25, no. 2, pp. 452-459. http:// dx.doi.org/10.1093/ee/25.2.452.

LEITE, G.L.D., VELOSO, R.V.D.S., ZANUNCIO, J.C., ALMEIDA, C.I.M.E., FERREIRA, P.S.F., FERNANDES, G.W. and SOARES, M.A., 2012. Habitat complexity and Caryocar brasiliense herbivores (insecta: Arachnida: Araneae). The Florida Entomologist, vol. 95, no. 4, pp. 819-830. http://dx.doi.org/10.1653/024.095.0402.

LEITE, G.L.D., VELOSO, R.V.D.S., ZANUNCIO, J.C., AZEVEDO, A.M., SILVA, J.L., WILCKEN, C.F. and SOARES, M.A., 2017. Architectural diversity and galling insects on Caryocar brasiliense trees. Scientific Reports, vol. 7, no. 1, pp. 16677. http://dx.doi. org/10.1038/s41598-017-16954-6. PMid:29192234.

LEITE, G.L.D., VELOSO, R.V.S., ZANUNCIO, J.C., ALVES, S.M., AMORIM, C.A.D. and SOUZA, O.F.F., 2011. Factors Affecting Constrictotermes cyphergaster (Isoptera: Termitidae) Nesting on Caryocar brasiliense Trees in the Brazilian Savanna. Sociobiology, vol. 57, no. 1, pp. 165-180.

MACEDO, M.O., RESENDE, A.S., GARCIA, P.C., BODDEY, R.M., JANTALIA, C.P., URQUIAGA, S., CAMPELLO, E.F.C. and FRANCO, A.A., 2008. Changes in soil $C$ and $N$ stocks and nutrient dynamics 13 years after recovery of degraded land using leguminous nitrogen- 
fixing trees. Forest Ecology and Management, vol. 255, no. 5-6, pp. 1516-1524. http://dx.doi.org/10.1016/j.foreco.2007.11.007.

MCLEISH, M.J., CHAPMAN, T.W. and SCHWARZ, M.P., 2007. Hostdriven diversification of gall-inducing Acacia thrips and the aridification of Australia. BMC Biology, vol. 5, no. 3, pp. 1-13. http://dx.doi.org/10.1186/1741-7007-5-3. PMid:17257412.

MUTHUKUMAR, T. and UDAIYAN, K., 2018. Coinoculation of bioinoculants improve Acacia auriculiformis seedling growth and quality in a tropical Alfisol soil. Journal of Forestry Research, vol. 29, no. 3, pp. 663-673. http://dx.doi.org/10.1007/s11676017-0497-1.

NOGUEIRA, T.A.R., SAMPAIO, R.A., FONSECA, I.M., FERREIRA, C.S., SANTOS, S.E., FERREIRA, L.C., GOMES, E. and FERNANDES, L.A., 2007. Metais pesados e patógenos em milho e feijão caupi consorciados, adubados com lodo de esgoto. Revista Brasileira de Engenharia Agrícola e Ambiental, vol. 11, no. 3, pp. 331-338. http://dx.doi.org/10.1590/S1415-43662007000300014.

OSEI-TUTU, G., ABUNYEWA, A.A., DAWOE, E.K., AGBENYEGA, O. and BARNES, R.V., 2018. Effect of multipurpose trees and shrubs on degraded mined-out soil in a semi-deciduous forest zone of West Africa. Land Degradation E' Development, vol. 29, no. 10, pp. 3432-3439. http://dx.doi.org/10.1002/ldr.3110.

PEARCE, J.L. and VENIER, L.A., 2006. The use of ground beetles (Coleoptera: Carabidae) and spiders (Araneae) as bioindicators of sustainable forest management: A review. Ecological Indicators, vol. 6, no. 4, pp. 780-793. http://dx.doi.org/10.1016/j. ecolind.2005.03.005.

PEGORARO, R.F., MOREIRA, C.G., DIAS, D.G. and SILVEIRA, T.C., 2018. Carbon and nitrogen stocks in the soil and humic substances of agricultural crops in the semi-arid region. Ciência Agronômica, vol. 49, no. 4, pp. 574-583. http://dx.doi.org/10.5935/18066690.20180065 .

PODEROSO, J.C.M., DA COSTA, M.K.M., CORREIA-OLIVEIRA, M.E., DANTAS, P.C., ZANUNCIO, J.C. and RIBEIRO, G.T., 2013. Occurrence of Tropidacris collaris (orthoptera: Acridoidea: Romaleidae) damaging Casuarina glauca (casuarinaceae) plants in the municipality of central Bahia, Brazil. The Florida Entomologist, vol. 96, no. 1, pp. 268-269. http://dx.doi.org/10.1653/024.096.0143.

RAHMAN, M.M., RAHMAN, M.A., MIAH, M.G., SAHA, S.R., KARIM, M.A. and MOSTOFA, M.G., 2017. Mechanistic insight into salt tolerance of Acacia auriculiformis: the importance of ion selectivity, osmoprotection, tissue tolerance, and $\mathrm{Na}+$ exclusion. Frontiers in Plant Science, vol. 8, pp. 155. http://dx.doi. org/10.3389/fpls.2017.00155. PMid:28421081.

RIIHIMÄKI, J., VEHVILÄINEN, H., KAITANIEMI, P. and KORICHEVA, J., 2006. Host tree architecture mediates the effect of predators on herbivore survival. Ecological Entomology, vol. 31, no. 3, pp. 227-235. http://dx.doi.org/10.1111/j.1365-2311.2006.00784.x.

ROJAS, J.M., PRAUSE, J., SANZANO, G.A., ARCE, O.E.A. and SÁNCHEZ, M.C., 2016. Soil quality indicators selection by mixed models and multivariate techniques in deforested areas for agricultural use in NW of Chaco, Argentina. Soil \& Tillage Research, vol. 155, pp. 250-262. http://dx.doi.org/10.1016/j.still.2015.08.010.

SALOV, G.I., 2014. On the power of a new statistical test and twosample Wilcoxon test. Optoelectronics, Instrumentation and Data Processing, vol. 50, no. 1, pp. 36-48. http://dx.doi.org/10.3103/ S8756699014010051.
SANTANA, P.H.L., FRAZÃO, L.A., SANTOS, L.D.T., FERNANDES, L.A. and SAMPAIO, R.A., 2016. Soil attributes and production of eucalyptus in monoculture and silvopastoral systems in the North of Minas Gerais, Brazil. Journal of Agricultural Science and Technology B, vol. 6, no. 6, pp. 361-370. http://dx.doi. org/10.17265/2161-6264/2016.06.001.

SILVA, J.L., DEMOLIN LEITE, G.L., DE SOUZA TAVARES, W., SOUZA SILVA, F.W., SAMPAIO, R.A., AZEVEDO, A.M., SERRÃO, J.E. and ZANUNCIO, J.C., 2020. Diversity of arthropods on Acacia mangium (Fabaceae) and production of this plant with dehydrated sewage sludge in degraded area. Royal Society Open Science, vol. 7, no. 2, pp. 191196. http://dx.doi.org/10.1098/rsos.191196. PMid:32257306.

SOLAR, R.R., BARLOW, J., FERREIRA, J., BERENGUER, E., LEES, A.C., THOMSON, J.R., LOUZADA, J., MAUÉS, M., MOURA, N.G., OLIVEIRA, V.H., CHAUL, J.C., SCHOEREDER, J.H., VIEIRA, I.C., MAC NALLY, R. and GARDNER, T.A., 2015. How pervasive is biotic homogenization in human-modified tropical forest landscapes? Ecology Letters, vol. 18, no. 10, pp. 1108-1118. http:// dx.doi.org/10.1111/ele.12494. PMid:26299405.

WHISENANT, S.G., 1999. Repairing damaged wildlands: a processoriented. Landscape-Scale Approach, vol. 76, no. 1, pp. 106. http:// dx.doi.org/10.1086/393832.

WILCOXON, F., 1946. Individual comparisons of grouped data by ranking methods. Journal of Economic Entomology, vol. 39, no. 6, pp. 269-270. http://dx.doi.org/10.1093/jee/39.2.269. PMid:20983181.

WU, D., FENG, J., CHU, S., JACOBS, D.F., TONG, X., ZHAO, Q., CHEN, X. and ZENG, S., 2019. Integrated application of sewage sludge, earthworms and Jatropha curcas on abandoned rare-earth mine land soil. Chemosphere, vol. 214, pp. 47-54. http://dx.doi. org/10.1016/j.chemosphere.2018.09.087. PMid:30253255.

ZALEWSKI, M., HAJDAMOWICZ, I., STAŃSKA, M., DUDEK-GODEAU, D., TYKARSKI, P., SIENKIEWICZ, P., CIURZYCKI, W. and ULRICH, W., 2018. B-diversity decreases with increasing trophic rank in plant - arthropod food chains on lake islands. Scientific Reports, vol. 8, no. 1, pp. 1-8. http://dx.doi.org/10.1038/s41598018-34768-y.

ZHOU, Y., HE, Y., HE, Y., LIU, X., XU, B., YU, J., DAI, C., HUANG, A., PANG, Y. and LUO, L., 2019. Analyses of tetracycline adsorption on alkali-acid modified magnetic biochar: site energy distribution consideration. The Science of the Total Environment, vol. 650, no. Pt 2, pp. 2260-2266. http://dx.doi.org/10.1016/j. scitotenv.2018.09.393. PMid:30292119.

ZHU, X., CHEN, H., ZHANG, W., HUANG, J., FU, S., LIU, Z. and MO, J., 2016. Effects of nitrogen addition on litter decomposition and nutrient release in two tropical plantations with N2-fixing vs. non-N2-fixing tree species. Plant and Soil, vol. 399, no. 1-2, pp. 61-74. http://dx.doi.org/10.1007/s11104-015-2676-1.

ZOGRAFOU, K., ADAMIDIS, G.C., KOMNENOV, M., KATI, V., SOTIRAKOPOULOS, P., PITTA, E. and CHATZAKI, M., 2017. Diversity of spiders and orthopterans respond to intra-seasonal and spatial environmental changes. Journal of Insect Conservation, vol. 21, no. 3, pp. 531-543. http://dx.doi.org/10.1007/s10841-017-9993-z.

ZVEREVA, E.L., ZVEREV, V. and KOZLOV, M.V., 2014. High densities of leaf-tiers in open habitats are explained by host plant architecture. Ecological Entomology, vol. 39, no. 4, pp. 470-479. http://dx.doi.org/10.1111/een.12123. 